Mykola Stadnyk, Advanced Doctor in Phylosophical Sciences, Prof.

National Academy for Public Administration under the President of Ukraine, Kyiv, Ukraine

\title{
SCIENCE AND RELIGION IN THE CATHOLIC DOCTRINE: COADAPTIVE TRENDS
}

Theoretical approaches to the co-adaptation of science and religion in Catholicism are revealed. The metaphysical substantiation of the existence of the supernatural is shown. The multifaceted arguments for the defense of the idea of creation are based on references to the limited and historical underdevelopment of human practice, evidence of the presence of uncontrolled, almost undeveloped, and therefore incomprehensible phenomena of nature, society and the human psyche. A characteristic feature of theological knowledge is not systematic, but spontaneity, at their basis is the rational substantiation of the irrational. The process of cognition for Catholic theologians presupposes the dominance of faith and the silence of reason. This understanding of the process of cognition and the role of science has changed over the course of historical time. Under the influence of the growing role of science, Catholic theologians began to highlight in certain issues not only the possible combination of religion with scientific knowledge, but also to prove the beneficial influence of religion on science. In the Catholic understanding, this points to the leading role of religion in the emergence of science. At the same time, scientific knowledge strives for objective significance and maximum accuracy. The Catholic doctrine of creation not only recognizes subjectivism, but also identifies theological faith and inner experience with the criterion of truth. A comparative analysis of scientific and theological knowledge shows that their purpose, methods and criteria of knowledge are essentially opposite.

Keywords: Catholic doctrine, theological knowledge, scientific knowledge.

УДК $32.001(075.8)$

DOI: 10.17721/sophia.2021.17.4

О. І. Ткач, д-р політ. наук, проф. Київський національний університет імені Тараса Шевченка, Київ, Україна ORCID: 0000-0003-3131-1533 e-mail: tio19@ukr.net

\section{СПІВВІДНОШЕННЯ ДЕМОКРАТИЗАЦІЇ ТА РЕЛІГІЙНОЇ БЕЗПЕКИ}

Розглянуто проблеми загроз релігійній безпеці. Релігія як відносно незалежна соціально-культурна реальність потребує захисту від внутрішніх і зовнішніх загроз. Релігійна безпека - це система умов, що забезпечує збереження традиційної релігійної системи в межах усталеної норми, що склалася історично. Проблема релігійної безпеки була виявлена, коли випадки антидержавної, антигромадської діяльності релігійних об'єднань почастішали.

Використовувались такі методи дослідження: загальнонаукові методи - системний, структурно-функціональний, порівняльний; логічні методи - емпіричне, статистичне, прогностичне моделювання та аналіз. Перевага віддавалася методу системного аналізу, за допомогою якого було визначено особливості розв'язання проблеми релігійної безпеки.

Визначено, що, оскільки релігія впливає на політику й право, рівень актуальності релігійної безпеки зростає. У сучасних умовах перехідних режимів реліеійна система стає важливим фактором політичної стабільності. Особливо це стосується традиційної релігійної системи, яка має історію розвитку, глибоку систему в народній культурі. У геополітичному протистоянні також важливу роль відіграє релігійний фактор. Ситуація вимагає мобілізації ресурсів релігійної безпеки суспільства. Серед завдань є проблема підготовки ідеологічних кадрів, наприклад політологів, філософів, які мають здатність протистояти ідеологічному впливу. Актуальною є проблема формування ефективної релігійної ідеології, яка враховує геополітичне суперництво держав, посилення динаміки духовної конкуренції, духовної експансії.

Загроза релігійній безпеці полягає в тому, що Латинська Америка як один із центрів католицизму у світі стоїть перед ідеологічним вибором. 3 одного боку, вона може повернутися в лоно римо-католицької церкви. Оскільки в регіоні зростає рівень взаємозв'язку держави та суспільства, то існує потреба в комплексі заходів із метою забезпечення релігійної безпеки. Розкрито особливості шляхів і засобів протидії релігійній небезпеці. Влада спрямовує зусилля на реалізацію реформ, які стануть гарантією стабільного політичного режиму.

Ключові слова: політичний процес, релігійна безпека, релігійна криза, Латинська Америка, стратегії подолання загроз релігійної безпеки, стабільний політичний режим, релігійна концепція безпеки.

Вважається, що релігійні вірування формують політичні погляди, а не навпаки. Але нещодавні дані свідчать, що причинно-наслідковий зв'язок може відбуватися іншим шляхом: дослідження показали, що багато людей спочатку змінюють свої політичні погляди, а потім стають менш релігійними.

Протягом століть релігія служила силою соціальної згуртованості, знижуючи рівень злочинності і заохочуючи дотримання закону. Релігійні консерватори побоюються, що відступ від релігії призведе до соціального безладдя, зростання рівня корупції і злочинності. Проте, що дивно, це побоювання не підтверджується доказами.

Група спостереження Transparency International відстежує відносну корупцію і чесність державних чиновників і бізнесу, публікує Індекс сприйняття корупції, що оцінює корупцію в державному секторі в 180 країнах і територіях. Ці дані дозволяють перевірити реальний взаємозв'язок між релігійністю і корупцією: невже корупція менш поширена в релігійних країнах, ніж у менш релігійних? Насправді релігійні країни звичайно більш корумповані, ніж світські. У світських державах Північної Європи найнижчий рівень корупції у світі, а у високорелігійних країнах - один із найвищих (Бангладеш, Гватемала, Ірак, Танзанія і Зімбабве) (www.Transperency.org).
Звісно, релігійність не викликає корупції. Країни 3 низьким рівнем економічної і фрізичної безпеки, як правило, мають високий рівень релігійності, а також високий рівень корупції. Хоча колись релігія могла відіграти вирішальну роль у підтримці суспільної моралі, ця роль зменшується в міру економічного розвитку суспільства. Населення релігійних країн частіше засуджує корупцію, ніж населення менш релігійних країн. Релігія може зробити людей жорстокими, але не робить їх менш корумпованими.

У країнах з високим рівнем безпеки і секулярності люди надають більше значення самовираженню і вільному вибору, приділяючи увагу правам людини, захисту навколишнього середовища, гендерній рівності, свободі вибору.

У ранніх аграрних суспільствах, коли більшість людей ледве досягали рівня виживання, релігія могла бути найбільш ефективним способом підтримки порядку і згуртованості. Але модернізація змінила рівняння. У міру того, як традиційна релігійність занепадає, здається, з'являється комплекс моральних норм, щоб заповнити порожнечу.

Рівень безпеки сприяє тенденції до зниження значення релігії в житті людей. Вони менше прислухову- 
ються до традиційних релігійних лідерів, інститутів. Зокрема, пандемія COVID-19 знижує почуття екзистенціальної безпеки людей. Якщо пандемія триватиме багато років або призведе до нової Великої депресії, то культурні зміни можуть мати регрес (Pandemic Backsliding V-Dem. URL: https://www.v-dem.net. 2021).

Рональд Ф. Інглхарт, почесний професор демократії, демократизації і прав людини Мічиганського університету Емі та Алан Ловенстайн в праці "Раптовий занепад релігії: причини і що буде далі?" визначив, що в перші роки двадцять першого століття релігія, здавалося, була на підйомі. Крах комунізму і Радянського Союзу залишив ідеологічний вакуум, що заповнювався православним християнством у пострадянських державах. Обрання в Сполучених Штатах президента Джорджа Буша, євангелічного християнина, свідчило про те, що євангельське християнство ставало політичною силою в країні. А теракти 11 вересня привернули міжнародну увагу до сили політичного ісламу в мусульманському світі [3].

Піппа Норріс проаналізувала дані про релігійні тенденції в 49 країнах, включаючи субнаціональні території, такі як Північна Ірландія, щодо яких було отримано дані опитування з 1981 до 2007 року включно (у цих країнах проживало 60 відсотків населення світу). Автори не знайшли повсюдного відродження релігії, але, незважаючи на твердження, що більшість країн з високим рівнем доходів стали менш релігійними, знайшли, що в 33 з 49 країн, які вони вивчили, люди стали більш релігійними за ці роки. Так було в більшості колишніх комуністичних країн, у більшості країн, що розвиваються, і навіть у країнах з високим рівнем доходів. Результати ясно показали, що індустріалізація і поширення наукових знань не призвели до зникнення релігії, як колись припускали деякі вчені [5].

Але з 2007 року все змінилося з дивною швидкістю. Приблизно з 2007 до 2019 року включно переважна більшість досліджуваних країн - 43 із 49 - стали менш релігійними. Зниження віри не обмежувалося країнами з високим рівнем доходів і спостерігалося в більшості країн світу.

Багато людей більше не вважають релігію необхідним джерелом підтримки і змісту свого життя. Навіть Сполучені Штати, що довгий час вважалися доказом того, що економічно розвинуте суспільство може бути сильно релігійним, тепер приєдналися до інших багатих країн у їхньому відході від релігії. Цю тенденцію рухають кілька сил, але найдужча з них - це ослаблення переконань, тісно пов'язаних з імперативом підтримки високої народжуваності. Сучасні суспільства стали менш релігійними почасти тому, що їм більше не потрібно дотримуватися гендерних і сексуальних норм, що основні світові релігії поширювали століттями.

Хоча деякі релігійні консерватори попереджають, що відступ від віри призведе до краху соціальної згуртованості і моралі, докази не підтверджують це твердження. Менш релігійні країни, як правило, менш корумповані і мають більш низький рівень убивств, ніж більш релігійні. Зайве говорити, що сама релігія не заохочує корупцію і злочинність. Це явище відбиває той факт, що в міру розвитку суспільства виживання стає більш безпечним: голод, колись поширений, стає рідкістю; збільшується тривалість життя; зменшуються убивства й інші форми насильства. І в міру підвищення цього рівня безпеки люди стають менш релігійними.

Дослідження Рональда Ф. Інглхарта, опубліковане в 2011 році, порівнювало рівні релігійних переконань за статистикою 1981 р. із результатами опитувань, починаючи з 2007 року, за період приблизно чверть століття. В опитуванні респондентів просили вказати, наскі- льки важливий Бог у їхньому житті, вибравши значення по шкалі від одного - "Зовсім не важливо" - до десяти "Дуже важливо". Вивчення того, як рівень релігійності країни змінюється з часом, призвело до деяких разючих результатів. У більшості опитаних країн спостерігається ріст віри у важливість Бога. Найбільший ріст був у колишніх комуністичних країнах. Наприклад, з 1981 до 2007 року включно середній бал релігійності болгарської публіки виріс з 3,6 до 5,7. У Росії він виріс з 4,0 до 6,0 . Частково цей ріст релігійності був відповіддю на різке зниження економічної, фрізичної і психологічної безпеки, що відбулося після розпаду Радянського Союзу; релігія заповнювала ідеологічний вакуум, що залишився після краху комунізму. Релігійні переконання також збільшилися в багатьох країнах, що розвиваються, за межами колишнього Радянського Союзу, включаючи Бразилію, Китай, Мексику і Південну Афррику. 3 іншого боку, релігія занепала в більшості країн 3 високим рівнем доходів [3].

32007 року спостерігається різка тенденція відходу від релігії. Практично у всіх країнах з високим рівнем доходу релігія продовжує занепадати. Водночас багато бідних країн разом з більшістю колишніх комуністичних держав також стали менш релігійними. 32007 до 2019 року включно лише п'ять країн стали більш релігійними, тоді як переважна більшість досліджених країн рухалася в протилежному напряму.

Індія - найважливіший виняток із загальної картини занепаду релігійності. Період дослідження приблизно збігається з поверненням до влади індуїстської націоналістичної партії Бхаратія Джаната, чий політичний курс прагне об'єднати національну ідентичність з релігійною ідентичністю. Уряд БДП виступає за політику, що дискримінує послідовників інших релігій, зокрема, численна мусульманська меншість Індії, поляризує громади і розпалює релігійні почуття.

Відхід від релігії відбувся серед американської громадськості. 31981 до 2007 року включно Сполучені Штати вважалися однією із самих релігійних країн у світі, де рівень релігійності мінявся дуже мало. 3 того часу Сполучені Штати продемонстрували найбільший відхід від релігії серед усіх країн, з яких є дані. Ближче до кінця початкового періоду дослідження середня оцінка американцями важливості Бога в їхньому житті становила 8,2 за десятибальною шкалою. Відповідно до дослідження, проведеного в США в 2017 році, цей показник упав до 4,6, що є різким зниженням. Протягом багатьох років Сполучені Штати були ключовим прикладом, що демонструє, що економічна модернізація не обов'язково призводить до секуляризації. За цим показником Сполучені Штати перебувають на 11 місці серед найменш релігійних країн.

Дослідники М. Вебер і Е. Дюркгейм пророкували, що поширення наукових знань розвіє релігію в усьому світі, але цього не відбулося. Для більшості людей релігійна віра була більш емоційною, ніж пізнавальною. І протягом більшої частини історії людства саме виживання було невизначеним. Релігія давала впевненість у тім, що світ перебуває в руках непогрішної вищої сили, яка обіцяла, що, якщо хтось буде дотримуватися правил, буде позитив. У світі, у якому люди часто жили на межі голоду, релігія допомогла їм упоратися із серйозною невизначеністю і стресом. Але в міру економічного і технологічного розвитку люди уникали голоду, долали хвороби і придушували насильство. Вони стають менш залежними від релігії, менш схильні миритися з її обмеженнями, через зменшення екзистенціальної незахищеності і росту тривалості життя [2; 6; 7; 8]. 
Секуляризація не відбувається відразу скрізь; це відбувається, коли країни досягли високого рівня екзистенціальної безпеки, і навіть у цьому разі рухається повільними темпами, коли одне покоління змінює інше, може навіть повернути назад, коли суспільства стануть більш релігійними, якщо вони будуть випробувати тривалі періоди зниження рівня безпеки. Секуляризація поступово відбувається з дев'ятнадцятого століття, починаючи із суспільств Західної Європи і Північної Америки, які були найбільш безпечними економічно і фрізично, а потім поширилися.

Хоча секуляризація звичайно відбувається за умови швидких темпів зміни населення з покоління в покоління, може досягти переломного моменту, коли переважна думка зміниться і люди, за впливу сил конформізму і соціальних потреб, почнуть віддавати перевагу поглядам, проти яких вони колись виступали, що призведе до винятково швидких культурних змін. Недавно цей поріг досягли більш молоді і більш освічені групи в країнах з високим рівнем доходів.

Фактор підвищення рівня економічного і технологічного розвитку пояснює занепад релігії. У США політика частково пояснює спад. 3 1990-х років Республіканська партія прагнула заручатися підтримкою, дотримаючись консервативних християнських позицій стосовно одностатевих шлюбів, абортів та інших культурних проблем. Але цей політичний заклик до релігійних виборців мав побічний ефект відштовхування інших виборців, особливо молодих, ліберальних щодо культурних відносин, від релігії [3].

Ці фактори змусили євангелістів побоюватися, що молоді люди масово залишать свої церкви, що прискориться ця тенденція. Римо-католицька церква, зі свого боку, втратила прихильників через власну кризу. Дослідницький центр Pew Research Center дослідив, що 92 відсотка дорослого населення США були інформовані про недавні повідомлення про сексуальне насильство з боку католицьких священиків, близько 80 відсотків опитаних заявили, що, на їхню думку, ці порушення були "тривалими проблемами, що все ще існують". Відповідно, 27 відсотків опитаних католиків США заявили, що вони скоротили відвідуваність меси у відповідь на ці повідомлення (Pew Research Center. URL: www.pewresearch.org).

П. Норріс визначила, що основні світові релігії уявляли норми, які сприяли народжуваності, як абсолютні моральні правила, тому пручалися змінам. Люди повільно відмовлялися від звичних переконань і соціальних ролей, які вони знали з дитинства стосовно статі і сексуальної поведінки. Але коли суспільство досягло досить високого рівня економічної і фрізичної безпеки, молоді покоління виросли, приймаючи цю безпеку як належне, норми народжуваності відступили. Ідеї, практика і закони, що стосуються гендерної рівності, розлучень, абортів і гомосексуалізму, швидко змінюються [4].

У звітах Світового огляду цінностей (World Values Survey) можна побачити глибоку трансформацію. В опитуванні використовується десятибальна шкала, заснована на прийнятті кожною країною розводів, абортів і гомосексуалізму. Переламний момент міститься приблизно в середині шкали, на рівні 5,50: більш низькі бали вказують на те, що більшість жителів країни дотримуються консервативніших поглядів, а більш високі бали вказують на те, що більшість дотримується ліберальніших поглядів, заснованих на особистому виборі. Приблизно в 1981 р. більшість у кожній країні підтримувала норми, які сприяють народжуваності. Навіть у країнах 3 високим рівнем доходу середній бал варіювався від 3,44 (Іспанія), 3,49 (США), 3,50 (Японія), 4,14 (Вели- ка Британія) і 4,63 (Фінляндія) до 5,35 для Швеції (WVS Database. URL: www. worldvaluessurvey).

Проте відбувалися глибокі зміни. До 2019 року середній бал Іспанії виріс до 6,74, США - до 5,86, Японії до 6,17, Великої Британії - до 6,90, Фінляндії - до 7,35 і Швеції - до 8,49. Показники були нижчі ніж точка 5,50 за першого опитування, усі вони були вищими від неї до 2019 року. Ці цифри пропонують спрощену картину складної реальності, але вони передають масштаби недавнього прискорення секуляризації.

Тенденція поширилася на весь інший світ. Проте населення 18 країн з мусульманською більшістю перебувало набагато нижче від критичної точки, залишаючись релігійним, прихильником збереження традиційних норм, які стосуються статі і народжуваності. Навіть контролюючи економічний розвиток, країни з мусульманською більшістю $є$ трохи релігійнішими, консервативнішими в культурних відносинах, ніж за середнім показником.

В Україні соціально-політична інтенціональність комунікації релігійних організацій проявляється через інституціональні і неінституціональні форми впливу. До форми інституціонального впливу належать: візити та зустрічі офріційних представників релігійних і міжрелігійних (ВРЦРО) організацій з політичними лідерами та високопосадовцями України, зарубіжжя та інформатизація міжнародної громадськості про стан справ в державі та позиції релігійних організацій; здійснення капеланської роботи, підтримка (моральна, матеріальна) релігійними організаціями військових та волонтерів у поєднанні з постійним вихованням патріотизму та національної ідеї; діяльність релігійних організацій спрямована на формування світогляду вірян, зокрема політичного (наприклад, проведення соціальних та освітніх заходів та ініціатив релігійними організаціями щодо соціальнополітичних проблем та питань в державі) [1, с. 12].

Дослідження ціннісно-релігійних засад сучасного зовнішньополітичного процесу засвідчило, що вплив ідей, ідеалів на політичну реальність досить значний, не зводиться винятково до сфери політичної культури, спираючись на розмитіше розуміння в суспільній свідомості ідеалу справедливого суспільного устрою, реалізованого в різних тенденціях трансформації політичної риторики.

Список використаної літератури

1. Гриньків М. В. Вплив релігійних організацій на політичний процес в Україні: автореф. дис. ... канд. політ. наук : 23.00.02 / Гриньків Марія Володимирівна. - К., 2018.

2. Durkheim Emile. The Elementary Forms of the Religious Life / Emile Durkheim. - London : George Allen \& Unwin, 2012.

3. Inglehart Ronald F. Giving Up on God. The Global Decline of Religion [Electronic resource] / Ronald F. Inglehart // Foreign Affairs. September/October 2020, Mode of access: https://www.foreignaffairs.com/ articles/world/2020-08-11/religion-giving-god/

4. Norris Pippa. Cultural Backlash / Pippa Norris and Ronald Inglehart. - New York : Cambridge University Press, 2019.

5. Norris Pippa. Sacred and Secular: Politics and Religion Worldwide / Pippa Norris and Ronald Inglehart. - New York : Cambridge, 2004

6. Weber Max. Die Wirtschaftsethik der Weltreligionen. Religionssoziologische Skizzen. Einleitung. Der Konfuzianismus I, II / Max Weber /I Archiv fur Sozialwissenschaft und Sozialpolitik. - Band 41., Heft 1. - 1916.

7. Weber Max. The Protestant Ethic and The Spirit of Capitalism I Max Weber. - Los Angeles : Roxbury Publishing; 2002.

8. Zaleski Pawel. Ideal Types in Max Weber's Sociology of Religion: Some Theoretical Inspirations for a Study of the Religious Field / Pawel Zaleski // Polish Sociological Review. - 2010. - № 3(171).

References

1. Grin'kiv, M. V. Vpliv religijnih organizacij na politichnij proces v Ukraïni (The influence of religious organizations on the political process in Ukraine). Kiïv, 2018.

2. Durkheim, Emile. The Elementary Forms of the Religious Life. London, George Allen \& Unwin, 2012.

3. Inglehart, Ronald F. Giving Up on God. The Global Decline of Religion. Foreign Affairs. September/October 2020, available at: https://www.foreignaffairs.com/articles/world/2020-08-11/religion-giving-god/ 4. Norris, Pippa and Inglehart, Ronald. Cultural Backlash. New York, Cambridge University Press, 2019. P. 20. 
5. Norris, Pippa and Inglehart, Ronald. Sacred and Secular: Politics and Religion Worldwide. New York, Cambridge, 2004.

6. Weber, Max The Protestant Ethic and The Spirit of Capitalism. Los Angeles, Roxbury Publishing, 2002.

7. Weber, Max. Die Wirtschaftsethik der Weltreligionen. Religionssoziologische Skizzen. Einleitung. Der Konfuzianismus I, II. Archiv fur Sozialwissenschaft und Sozialpolitik. 1916, Band 41, Heft 1.
8. Zaleski, Pawel. Ideal Types in Max Weber's Sociology of Religion: Some Theoretical Inspirations for a Study of the Religious Field. Polish Sociological Review. 2010, No 3(171).

Надійшла до редколегії 02.03.21

О. И. Ткач, д-р полит. наук, профр.

Киевский национальный университет имени Тараса Шевченко, Киев, Украина

\section{СООТНОШЕНИЕ ДЕМОКРАТИЗАЦИИ И РЕЛИГИОЗНОЙ БЕЗОПАСНОСТИ}

Рассматриваются проблемы угроз религиозной безопасности. Религия как относительно независимая социально-культурная реальность требует защиты от внутренних и внешних угроз. Религиозная безопасность - это система условий, которое обеспечивает сохранение традиционной религиозной системы в границах упроченной нормы, которая сложилась исторически. Проблема религиозной безопасности была выявлена, когда случаи антигосударственной, антиобщественной деятельности религиозных объединений участились.

Для решения изложенных в статье проблем предлагались следующие исследовательские приемы: общенаучные методы - системный, структурно-функциональный, сравнительный, логические методы - эмпирическое, статистическое, прогностическое моделирование и анализ. Преимущество предоставлялось методу системного анализа, с помощью которого были определены особенности решения проблемы религчозной безопасности.

Показано, что, поскольку религия влияет на политику и право, уровень актуальности религиозной безопасности возрастает. В современных условиях переходных режимов религиозная система становится важным фактором политической стабильности. В особенности это касается традиционной религиозной системы, которая имеет историю развития, глубокую систему в народной культуре. В геополитическом противостоянии также важную роль имеет религиозный фактор. Ситуация требует мобилизации ресурсов религиозной безопасности общества. Среди задач - проблема подготовки идеологических кадров, например, политологов, философов, которые имеют способность противостоять идеологическому влиянию. Актуальной есть проблема формирования эффективной религиозной идеологии, которая учитывает геополитическое соперничество государств, усиления динамики духовной конкуренции, духовной экспансии.

Уәроза религиозной безопасности состоит в том, что Латинская Америка, как один из центров католицизма в мире, стоит перед идеологическим выбором. С одной стороны, она может возвратиться в лоно римо-католической иеркви. Поскольку в регионе возрастает уровень взаимосвязи государства и общества, существует необходимость в комплексе мероприятий с иелью обеспечения религиозной безопасности. Раскрыт особенности путей и средств противодействия религиозной опасности. Влада направляет усилия на реализацию реформ, которые станут гарантией стабильного политического режима.

Ключевые слова: политический процесс, религиозная безопасность, религиозный кризис, Латинская Америка, стратегии преодоления угроз религиозной безопасности, стабильный политический режим, религиозная концепция безопасности.

Oleg Tkach, Advanced Doctor in Political Sciences, Prof.

Taras Shevchenko National University of Kyiv, Kyiv, Ukraine

\section{THE RELATIONSHIP BETWEEN DEMOCRATIZATION AND RELIGIOUS SECURITY}

The article examines the problems of the component $s$ of the concept of threats to religious security, for example, which are transformed into concepts. Religion as a relatively independent socio-cultural reality needs protection from internal and external threats. Religious security is a system of conditions that ensures the preservation of the traditional religious system within the established norm that has historically developed. The problem of religious security was identified when the cases of anti-state, anti-social activities of religious associations became more frequent.

Methodology: The following research methods were used to address the issues set in the article: general scientific methods - descriptive, systemic, structural-functional, comparative, institutional-comparative; general logical methods - empirical, statistical, prognostic modeling and analysis; special methods of political science. The preference was given to the method of political-system analysis, by which the common and distinctive characteristics of the basic components of soft power strategies were identified, reflecting existing political, public, information and other challenges for international relations and global development.

Results. As societies develop from agrarian to industrial to knowledge-based, growing existential security tends to reduce the importance of religion in people's lives and people become less obedient to traditional religious leaders and institutions. Research of the problem by scientists. Religion is characterized by the historical predominance of Catholic Christianity (40\% of the world's Catholics in the region).

Conclusions. Although some religious conservatives warn that the retreat from faith will lead to a collapse of social cohesion and public morality, the evidence doesn't support this claim. Surprising as it may seem, countries that are less religious actually tend to be less corrupt and have lower murder rates than religious ones.

Keywords: political process, religious security, religious crisis, strategies to overcome threats to religious safe, stable political regime, religious concept of security. 